\title{
O PROJETO POÉTICO-PENSANTE DE CLARICE LISPECTOR
}

\begin{abstract}
Rodrigo da Costa Araujo é Doutorando em Literatura Comparada pela UFF e Mestre em Ciência da Arte, também pela UFF. Professor de Teoria da Literatura, Literatura infantojuvenil e Arte Educação dos cursos de Letras e Pedagogia da FAFIMA Faculdade de Filosofia, Ciências e Letras de Macaé. Coautor das coletâneas Literatura e Interfaces e Leituras em Educação, lançadas recentemente pela Editora Opção. E-mail: rodricoara@uol.com.br
\end{abstract}

Ler o elegante livro Clarice Lispector: uma literatura pensante, de Evandro Nascimento permite pensar em alguns questionamentos iniciais: até onde vai o silêncio no texto de Clarice Lispector? Como é o modo de pensar nas ficções de Clarice? O que é o humano e o que é o animal? Quais estranhezas existem nessas aproximações? Essas e outras questões sugerem, parodiando o próprio título da obra, uma "leitura pensante", espécie de pensamento inquieto que o ensaísta defende.

Os ensaios, divididos em dois momentos, têm como proposta a noção de uma literatura pensante. A primeira seção, intitulada "Humanos, animais, plantas \& coisas", volta-se para uma abordagem mais ampla - com forte viés filosófico centrado na narrativa clariceana - das fronteiras e interseções entre humanos e não humanos, bem como das interfaces entre filosofia e literatura e aborda, também, o trato requintado dessas aproximações. A isso se seguem discussões sobre errâncias da ficção clariceana, as intricadas relações entre vida e poder, as implicações ético-estéticas na literatura, as sutilezas e as relações dessas descobertas com o corpo e com o imaginário.

A segunda seção do livro, intitulada "Outros Movimentos Simulados", aborda as metáforas do mal e a publicação das Cartas Perto do Coração, de Fernando Sabino, trocadas entre ele e a escritora de A Hora da Estrela. Importa a Evandro Nascimento ver essas "simulações" representadas em diversos gêneros textuais assinados pela ficcionista. Todos eles, de algum modo ou de outro, ajudam a mapear a literatura pensante da escritora. Segundo essas leituras, o pensamento na literatura clariciana implica o encontro inaudito com o outro/a outra, os quais não se reduzem à alteridade imediata, apontando, também, para a discussão do diferente.

Assim, um dos méritos deste Clarice Lispector: uma literatura pensante está justamente no fato de que as discussões acolhem esse lugar de leitura, assumindo a posição de instabilidade que lhes oferece a indomável obra clariceana para, a partir daí, pensá-la, interpretá-la, confrontá-la.

Algumas vezes, pela via do paradoxo e da transversalidade, Nascimento, baseado em Derrida, evidencia, sutilmente, em Clarice o que outros escritores já disseram, obliquamente, através da literatura: que a travessia das fronteiras entre as esferas humana e não humana consiste em reconhecer, ao mesmo tempo, as diferenças que distinguem os homens dos outros e a impossibilidade dessas diferenças serem mantidas como instâncias excludentes, uma vez que os humanos precisam se aceitar como animais para se tornarem humanos.

\footnotetext{
Revista Escrita

Rua Marquês de São Vicente, 225 Gávea/RJ CEP 22453-900 Brasil Ano 2012. Número 15. ISSN 1679-6888.
} escrita@puc-rio.br 
Na obra de Clarice, uma característica dessa reflexão seria a desconstrução de dicotomias ou categorias, como masculino e feminino, homem e animal ou mesmo animal e plantas. Ela, segundo Evandro Nascimento, tem ajudado a questionar os limites do humano, na medida mesma em que traz para seu espaço formas concorrentes em relação à tradição, tais como animais e objetos, texturas, paisagens, cores, trechos musicais, ruídos e silêncios.

A literatura pensante de Clarice, aos olhos sensíveis de Nascimento, é o resultado da interação de forças, indicando o caráter dubitativo, sedicioso e, por isso mesmo, aberto do literário. Não que o efeito de indecisão interpretativa seja garantido de antemão, qualquer texto mesmo o mais insidioso pode dar vez a uma leitura unívoca e até mesmo transcendental. Há, porém, textos que em sua composição sígnica resistem mais, desnorteando o incauto leitor na procura do significado último da obra.

Nesse processo, Clarice investiga até o limite entre o que é vivo e o que não é; um raciocínio que culmina na figura do ovo, uma imagem recorrente em sua poética. "Clarice investe de subjetividade as plantas e os objetos", diz Evandro Nascimento, retomando o livro Água Viva, em que ela faz referência aos sentimentos das flores, e Um Sopro de Vida, no qual um personagem, o Autor, cria uma personagem feminina, Ângela, que dá vida aos objetos. É por meio desses questionamentos que a obra de Clarice ganha uma dimensão política, estética e sensível na leitura realizada, transgressoramente, por Evandro Nascimento.

Nessas oposições, normalmente um dos elementos do par é diminuído. No momento em que prestamos atenção na singularidade do outro - do animal, da planta, do feminino -, há a possibilidade de esse outro afirmar-se. A ética, nesse caso, significa construir espaços para que o outro possa emergir, trazer à cena o que é excluído, diz o crítico, que traça um paralelo entre Clarice e o filósofo Derrida. A escritora, para ele, resolve, ficcionalmente, o que Derrida questiona, filosoficamente, quebrando as hierarquias entre o feminino e o masculino, ou entre o humano e o animal.

Não se trata de psicanalisar as relações entre homens e bichos segundo Clarice, mas de compreender como certo "estranhamento familiar" perpassa a visão de alteridade. O bestiário (e seu correlato objetivo, o mundo das coisas em geral) clariceano dispõe a força do literário naquilo que ele excede o humano, abrindo para além do horizonte histórico. Em outras palavras, indagar o bicho ou os bichos e seus homólogos via ficção ajuda a pensar alguns dos aspectos da estranha intuição literária. Sobre o bestiário ficcional clariceano e seus correlatos, Nascimento afirma que "A assinatura Clarice Lispector espraia sua fauna nos mais diversos textos, constituindo uma verdadeira zoo-grafia, termo que em grego designava a "pintura do vivo"" (Nascimento, 2012, p. 48).

Para Evandro Nascimento, "uma literatura pensante como a de Clarice é a que possibilita pensar o impensável; e só pode haver pensamento ali onde se dá o advento da alteridade enquanto tal, o outro como Outro ou Outra, em sua radical diferença" (Nascimento, 2012, p.24). Confirma-se, nas suas leituras, que as personagens 
clariceanas põem-se a repensar o sentido e o valor literário e, ao mesmo tempo, em tom discreto e irônico, introduzem fórmulas capazes de envolver grande variedade de assuntos e leitores, tomadas como alvos e como nutrientes imprescindíveis para que se criem e se movam obras com tantas direções. Obras com charme e riqueza, graças em grande parte, aos múltiplos estímulos recepcionais, quase sempre conflitantes e aproximados. Arte como forma de pensamento.

Reforçando o título e paratexto inicial da obra, como também alguns encaminhamentos ou protocolos de leitura, o crítico afirma que a "literatura pensante como a de Clarice Lispector é a que dessubstancializa o pensamento como função ontológica e existencial, lançando-o nas paragens do impensável dessublimado mundo das coisas" (Nascimento, 2012, p.66). Faz parte desse projeto de Clarice refletir sobre o fenômeno social das relações com os animais, incorporando à cena discursiva as linhas de força, também plurais, daquele que está a ler. Cria e diverte-se com o desejo do outro.

Transdisciplinar e pontual, a escrita de Evandro Nascimento, recorrendo a múltiplos arquivos, oferta-nos delicadas pistas, como se - também se utilizando das reflexões, das astúcias e da fineza da escritora - sugerisse protocolos de leitura e sutilezas da investigação crítica. A leitura da obra de Clarice, nesse caso, permite dizer e significar em face de aproximações com o não-eu, o outro, a outra. Aprendemos a ver o literário em sua transitividade, em suas operações de deslocamento, passando por processos, meios e estágios variados.

Além de fertilizar a vida crítica da literatura e ativar a práxis textual de Clarice Lispector, este livro convida-nos a saberes diferidos, enfocados sob ritmos, vontades e valores constituintes de nossas melhores pesquisas sobre a escritora.

Clarice Lispector: uma literatura pensante, de Evandro Nascimento, é um elogio à literatura de Clarice. Tais tentativas poéticas de "ler" essa suposta poética do animal na ficção clariceana não deixam, contudo, de reconduzir à questão do sujeito e da subjetividade. Essas reflexões, portanto, retomam o esforço da escritora em apreender, pelo processo discursivo e da trama retórica, o "eu" dos animais não humanos, entrar na pele deles, imaginar o que eles diriam se tivessem o domínio da linguagem humana, encarar uma subjetividade possível do mundo (ainda que inventada) desses outros, conjeturar sobre seus saberes acerca do mundo, da literatura e da humanidade.

\section{Referências}

NASCIMENTO, Evandro. Clarice Lispector: uma literatura pensante. Rio de Janeiro: Civilização Brasileira, 2012. 303 p. 